\title{
Exploring the Science Attitudes of Urban Diverse Gifted Middle School Students
}

\author{
Bobby Jeanpierre', Rachel Hallett-Njuguna ${ }^{2}$ \\ ${ }^{1}$ School of Teaching Learning and Leadership, College of Education and Human Performance, University of \\ Central Florida, Orlando, FL, USA \\ ${ }^{2}$ Seminole County Public Schools, Sanford, FL, USA \\ Email: bobby.jeanpierre@ucf.edu, Rachel hallett@scps.k12.fl.us
}

Received 15 July 2014; revised 5 August 2014; accepted 25 August 2014

Copyright (C) 2014 by authors and Scientific Research Publishing Inc.

This work is licensed under the Creative Commons Attribution International License (CC BY).

http://creativecommons.org/licenses/by/4.0/

(c) (1) 0pen Access

\begin{abstract}
STEM (Science, Technology, Engineering, and Mathematics) is a central focus in science education, research, economics and politics. With this increased focus on STEM, it is important to know urban gifted students' perceptions and attitudes toward science. Overall, these 6th and 8th grade gifted students reported a lack of interest in science. This is troubling, if we want to see more diversity in the science professions. One group, minority girls, did provide a bright spot in their responses which had not been commonly reported in the research literature. They liked science the most and were positive about science, which was encouraging. To develop a diverse STEM workforce, it is imperative to provide the quality of education and means to support all students interested in pursuing these fields, including urban diverse gifted students.
\end{abstract}

\section{Keywords}

Urban, Diverse, Gifted, STEM, Middle School, Science

\section{Introduction}

In an ever expanding-global workforce where STEM (Science, Technology, Engineering and Mathematics) enjoys a major prominence, knowing what urban diverse gifted students think about science is important. Evidently, urban diverse gifted students have their own perceptions and attitudes toward science. Perceptions are related to how students feel about science; whereas, attitude, as used in this article, dates back to a long standing description which is more specific than perceptions and is focused on students' interest, satisfaction and enjoyment of science (Gardner, 1975). But what are urban diverse gifted students' attitudes toward science? To date, few reports have existed on urban diverse gifted students' science attitudes. 
In the U.S., urban students face a number of challenges with reports of inner city classrooms as dismal places. Haberman (1991) describes a "pedagogy of poverty" that exists in urban settings. Pedagogy of poverty is characterized by a series of predominant teaching acts (e.g. giving information, asking questions, giving directions, making assignments, monitoring seatwork, reviewing assignments, giving tests, reviewing tests, assigning homework, reviewing homework, etc.) which are often performed to the exclusion of inquiry and problem solving experiences. These acts are not necessarily negative but when done to the exclusion of higher order thinking and problem solving, they may academically bring disadvantage to students in urban schools.

Even gifted students in urban school settings are not necessarily exempt from the kinds of teaching practices that do not support students becoming problem-solvers and problem-posers. Stevens (1993) stated, "Current teaching practices in many urban school classrooms have been responsible for keeping the academic achievement of poor and minority students at a very low level” (p. 273).

Although a number of challenges exist in many urban schools, research has found that student achievement can be predicted by their expectations, value, and interest in the subject (Heller \& Ziegler, 1996). This article elucidated perceptions and science attitudes as viewed through the lens of a group of 49 urban diverse gifted middle school students. Students' perceptions and attitudes of science are important. The hope for successful excellent education in urban settings is predicated on teachers and students having high expectations that permeate every aspect of teaching and learning. The importance of knowing and fostering positive science attitudes among gifted learners may also be central to increasing their participation in STEM professions. Therefore, students' perceptions of their science instruction were explored to learn how they feel about science and may inform teachers and administrators of how they can motivate and increase urban diverse gifted students' interests in science. Students' success in science is linked to the quality of teaching experience and teachers' expectations for their learning.

\section{Methodology}

The school is located in a large urban school district and has approximately $860 \mathrm{~K}-8$ students. Over $60 \%$ of the students participate in the free and reduced lunch program. The school also has a relatively high mobility rate (i.e., over $40 \%$ ). The 6 th and 8 th grade gifted students who had consistent attendance in their science class throughout the school year were invited to respond to a science attitude survey, which was administered during the last semester of the school year. The students in the study were representative of the five classes of gifted students in the school. One teacher taught all of the students in the gifted program science for three consecutive years.

The participants were male and female students represented both majority and minority students. The 49 participants were: 16 Caucasian males, 16 Caucasian females, 4 minority males and 13 minority females. Students identified for this gifted program were selected, in part, based on the scores they received on the State's standardized reading and mathematics tests. These 49 students met requirements to participate in the gifted program and provided insights about their perceptions of science.

\section{Results}

Students' perceptions of science are related to interests that can be either encouraged or stifled (Wenner, 2003). At times, causes for student disinterest are deeply ingrained and more complicated than whether the class was fun. The most commonly researched reasons why students disconnect from science content concern females, minorities, and/or low ability students (DeMars, 1999; Heller \& Ziegler, 1996; Li \& Adamson, 1995).

With this group of urban diverse gifted students, we wanted to know their attitudes toward science. To gather information on students' attitude towards science, permission was obtained to use a survey produced in the Student Watershed Research Project, 2006. The survey's reliability had been established by the SWRP based over 12 years of data collected by the authoring university as they sought to determine the effect of an environmental science program on students' science attitudes. Researchers in this project believed this survey items accurately reflected the established criteria for measuring student science attitudes and was appropriate for this study. Items were selected from the Student Watershed Research Project (2006), which focused on students' perceptions and attitudes toward science. First, students were asked to respond to the statement: "Science is one of my favorite subjects." Second, eight survey items were group together to get an idea of students' overall positive attitudes to learn science. An example of a positively worded item is: "Outside of school I talk with my friends/family about 
science." Third, five related items that represented negative feelings toward science were grouped together to get a holistic look at students' negative attitudes. An example of a negatively worded item is: "I do not want to take any more science classes than I have to." Collectively, survey items were divided into 3 parts for analysis: 1) responses to the statement, "Science is one of my favorite subjects"; 2) overall positive attitude score; and 3) overall negative attitude score. Survey items were rated using a Likert ranking from 5 (Strongly agree) to 1 (strongly disagree). As shown in Table 1, it provides the results of students' responses to survey items described above.

\section{Discussion}

Students' responses were insightful. The minority females felt most strongly that science was one of their favorite subjects (mean 4.08) and had the highest positive science attitude ratings (mean 20.54). Minority females also had the lowest negative feelings about science (mean 15.00). These 13 girls appear to have strong positive feelings about science. This finding is encouraging, whereas Caucasian females reported less favorable feelings about science. They were least likely to say science was their favorite subject (mean 2.94) and reported the lowest positive attitudes (mean 18.34). They also had the second highest negative science attitude score (mean 16.69). These findings are troubling and important. It supports the need to continue to give girls support, encouragement, and expand their opportunities and experiences in science. Minority female students continue to be

Table 1. Descriptive statistics.

\begin{tabular}{|c|c|c|c|c|c|}
\hline & Gender & Race & Mean & Std. Deviation & $\mathrm{N}$ \\
\hline \multirow{10}{*}{$\begin{array}{l}\text { Science is one of my } \\
\text { favorite subjects }\end{array}$} & \multirow{3}{*}{ Male } & Caucasian & 3.25 & 1.183 & 16 \\
\hline & & Minority & 3.00 & 1.414 & 4 \\
\hline & & Total & 3.20 & 1.196 & 20 \\
\hline & \multirow{3}{*}{ Female } & Caucasian & 2.94 & 1.611 & 16 \\
\hline & & Minority & 4.08 & 1.188 & 13 \\
\hline & & Total & 3.45 & 1.526 & 29 \\
\hline & \multirow{3}{*}{ Total } & Caucasian & 3.09 & 1.400 & 32 \\
\hline & & Minority & 3.82 & 1.286 & 17 \\
\hline & & Total & 3.35 & 1.393 & 49 \\
\hline & \multirow{3}{*}{ Male } & Caucasian & 19.38 & 3.931 & 16 \\
\hline \multirow[t]{9}{*}{ Positive } & & Minority & 20.25 & 7.411 & 4 \\
\hline & & Total & 19.55 & 4.582 & 20 \\
\hline & \multirow{3}{*}{ female } & Caucasian & 18.38 & 5.772 & 16 \\
\hline & & Minority & 20.54 & 5.206 & 13 \\
\hline & & Total & 19.34 & 5.537 & 29 \\
\hline & \multirow{3}{*}{ Total } & Caucasian & 18.88 & 4.884 & 32 \\
\hline & & Minority & 20.47 & 5.535 & 17 \\
\hline & & Total & 19.43 & 5.119 & 49 \\
\hline & \multirow{3}{*}{ Male } & Caucasian & 16.75 & 2.569 & 16 \\
\hline \multirow[t]{8}{*}{ Negative } & & Minority & 16.50 & 5.196 & 4 \\
\hline & & Total & 16.70 & 3.080 & 20 \\
\hline & \multirow{3}{*}{ Female } & Caucasian & 16.69 & 4.512 & 16 \\
\hline & & Minority & 15.00 & 4.830 & 13 \\
\hline & & Total & 15.93 & 4.652 & 29 \\
\hline & \multirow{3}{*}{ Total } & Caucasian & 16.72 & 3.612 & 32 \\
\hline & & Minority & 15.35 & 4.795 & 17 \\
\hline & & Total & 16.24 & 4.065 & 49 \\
\hline
\end{tabular}


underrepresented in most science fields and engineering. They need increased support and opportunities, starting in the elementary years to affect their interest in science. The number of girls entering science fields still needs to improve. It is also important that we keep girls interested in science throughout their K-12 experience, which is central to moving them through the STEM pipeline to professional science careers. It has been reported that experiences and expectations for success are determined, in part, by a student's attitude toward and motivation in science (Singh, Granville, \& Dika, 2002).

Overall, examining results of all survey items, male students had higher positive attitudes toward science than their female classmates. Regardless of the gender or ethnicity of these high ability students, their overall feelings toward science were lower than expected. Out of the total 40 points for the 8 combined positive attitude items, the mean was 19.43 or an average of 2.4 per question on a Likert scale (about halfway between Strongly Disagree and Disagree). Therefore, on average, students indicated that they "Disagreed" with the items that described positive aspects of science. However, research supports high ability students more often exhibit higher levels of interest and increased involvement in school than their general ability peers likely because of educated parents, family encouragement, self-confidence, and supportive networks of friends (Stake \& Mares, 2001). This may not always be the case for students in urban low SES (socioeconomic status) schools for their parents may not have the education and resources to support their interests in pursuing more advanced STEM fields.

\section{Conclusion}

The current focus on STEM can be compared to the fervor which existed during the 1950s with the launch of Sputnik and the extraordinary focus linking national security to public education goals, and economic interests. Today, in the U.S., it has been said that developing the STEM talent pool is of utmost importance to workforce development, national security, economic growth, and international competitiveness. Urban diverse gifted students should play a strong role in contributing to the STEM workforce pool. All urban students, including urban diverse gifted students should have every opportunity to enter and succeed in STEM professions. Identifying urban diverse gifted students' science interests and supporting their academic growth in science are central to helping them secure future STEM jobs, if, they desire so. Goodlad (2004) found that when asked which subject they liked, students ranked science second lowest of the common school subjects in all grade levels. Also, as students got older, their interest in science decreased (Upper Elementary 81\%, Junior High 66\%, and Senior High 64\%) (Goodlard, p. 116). This decline in percent of students who reported that they like science is troubling. In this study, urban minority females reported the lowest negative feelings toward science and highest favorability. This is very encouraging. We need educators, parents, family, friends and the community to support urban gifted females and all urban gifted students to ensure long lasting science interest and future STEM participation.

Students who are motivated have been found to have a more positive attitude toward science, and motivation can be improved by positive school experiences (Jones, 1997). Teachers are encouraged to develop a stimulating science classroom environment where discovery, inquiry, and problem solving are all part of fun and learning. Goodlad (2004) found that effective teaching strategies can improve not only student attitudes, over time, but student achievement. Urban diverse gifted students' perceptions and attitudes of science are even more important because they are the students who have the aptitude and achievement to actually make a difference in solving our future problems, if they have a more positive attitude toward science. These urban diverse gifted students' survey results were not as positive as had been hoped, but there is a silver lining. Of the respondents, gifted minority girls liked science most and had the highest positive rating of science. This is encouraging for minority females who are not entering STEM professions at significant numbers. We should continue to work to provide these students with positive experiences, doing science in a variety of settings, including out-of-school experiences mentoring them to keep their interest in science. These responses also showed the need to continue to provide these urban diverse gifted students with support and effective teaching strategies such as inquiry to improve their science attitude and achievement. The opportunity for science educators to facilitate the kind of learning that motivates and challenge urban diverse gifted students is supported in the Next Generation Science Standards. As school district administrators move forward with the implementation of the Next Generation Science Standards, teachers will be able to enhance inquiry teaching and learning in their classrooms through the implementation of the new science and engineering practices. The science practices (asking questions, carrying out investigations, analyzing data, obtaining, evaluating, communicating information, developing explana- 
tions, and using models) will support students experiencing science concepts in more depth, which is reinforced as they progress through grades K-12.

Urban diverse gifted students' talents are untapped resources. They possess the abilities and potential to help tackle current and future problems in an ever evolving global economy. Teachers can do their part to help urban diverse gifted students secure a rewarding future in STEM professions, if they choose so. We know that students' experiences and expectations for success are determined, in part, by their attitude toward and motivation in science. Teachers can make a difference in affecting students' motivation and attitudes toward science and their contributions to the success of urban diverse gifted students is definitely needed!

\section{Note}

The preparation of this manuscript was funded by a grant from the National Science Foundation (NSF, GrantREC-0447676)

\section{References}

DeMars, C. (1999). Does the Relationship between Motivation and Performance Differ with Ability? The Annual Meeting of the National Council on Measurement in Education, Montreal, Quebec.

Gardner, P. L. (1975). Attitudes to Science. Studies in Science Education, 2, 1-41. http://dx.doi.org/10.1080/03057267508559818

Goodlad, J. I. (2004). A Place Called School (20th Anniversary ed.). New York: McGraw-Hill.

Haberman, M. (1991). The Pedagogy of Poverty versus Good Teaching. Phi Delta Kappan, 73, 290-294.

Heller, K. A., \& Ziegler, A. (1996) Gender Differences in Mathematics and the Sciences: Can Attributional Retraining Improves the Performance of Gifted Females. Gifted Child Quarterly, 40, 200-210. http://dx.doi.org/10.1177/001698629604000405

Jones, L. S. (1997). Opening Doors with Informal Science: Exposure and Access for Our Underserved Students. Science Education, 81, 663-677. http://dx.doi.org/10.1002/(SICI)1098-237X(199711)81:6<663::AID-SCE4>3.0.CO;2-G

Li, A. K. F., \& Adamson, G. (1995). Motivational Patterns Related to Gifted Students’ Learning of Mathematics, Science and English: An Examination of Gender Differences. Journal for the Education of the Gifted, 18, 284-297. http://dx.doi.org/10.1177/016235329501800305

Singh, K., Granville, M., \& Dika, S. (2002). Mathematics and Science Achievement: Effects of Motivation, Interest, and Academic Engagement. Journal of Educational Research, 95, 323-332. http://dx.doi.org/10.1080/00220670209596607

Stake, J. E., \& Mares, K. R. (2001). Science Enrichment Programs for Gifted High School Girls and Boys: Predictors of Program Impact on Science Confidence and Motivation. Journal of Research in Science Teaching, 38, 1065-1088. http://dx.doi.org/10.1002/tea.10001

Stevens, F. I. (1993). Applying an Opportunity-To-Learn Conceptual Framework to the Investigation of the Effects of Teaching Practices via Secondary Analyses of Multiple-Case Study Summary Data. Journal of Negro Education, 62, 232248. http://dx.doi.org/10.2307/2295463

Student Watershed Research Project (2006). Post-SWRP Student Science Attitude Survey. Retrieved May 2, 2006 from Portland State University, Environmental Sciences and Resources Website: http://www.swrp.esr.pdx.edu/teacher_info/teacher_info.htm

Wenner, G. (2003). Comparing Poor, Minority Elementary Students’ Interest and Background in Science with That of Their White, Affluent Peers. Urban Education, 38, 153-172. http://dx.doi.org/10.1177/0042085902250483 
Scientific Research Publishing (SCIRP) is one of the largest Open Access journal publishers. It is currently publishing more than 200 open access, online, peer-reviewed journals covering a wide range of academic disciplines. SCIRP serves the worldwide academic communities and contributes to the progress and application of science with its publication.

Other selected journals from SCIRP are listed as below. Submit your manuscript to us via either submit@scirp.org or Online Submission Portal.
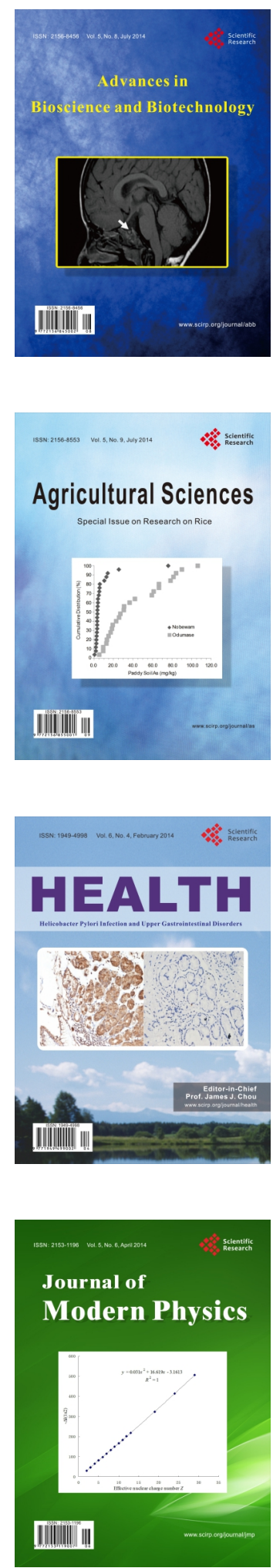
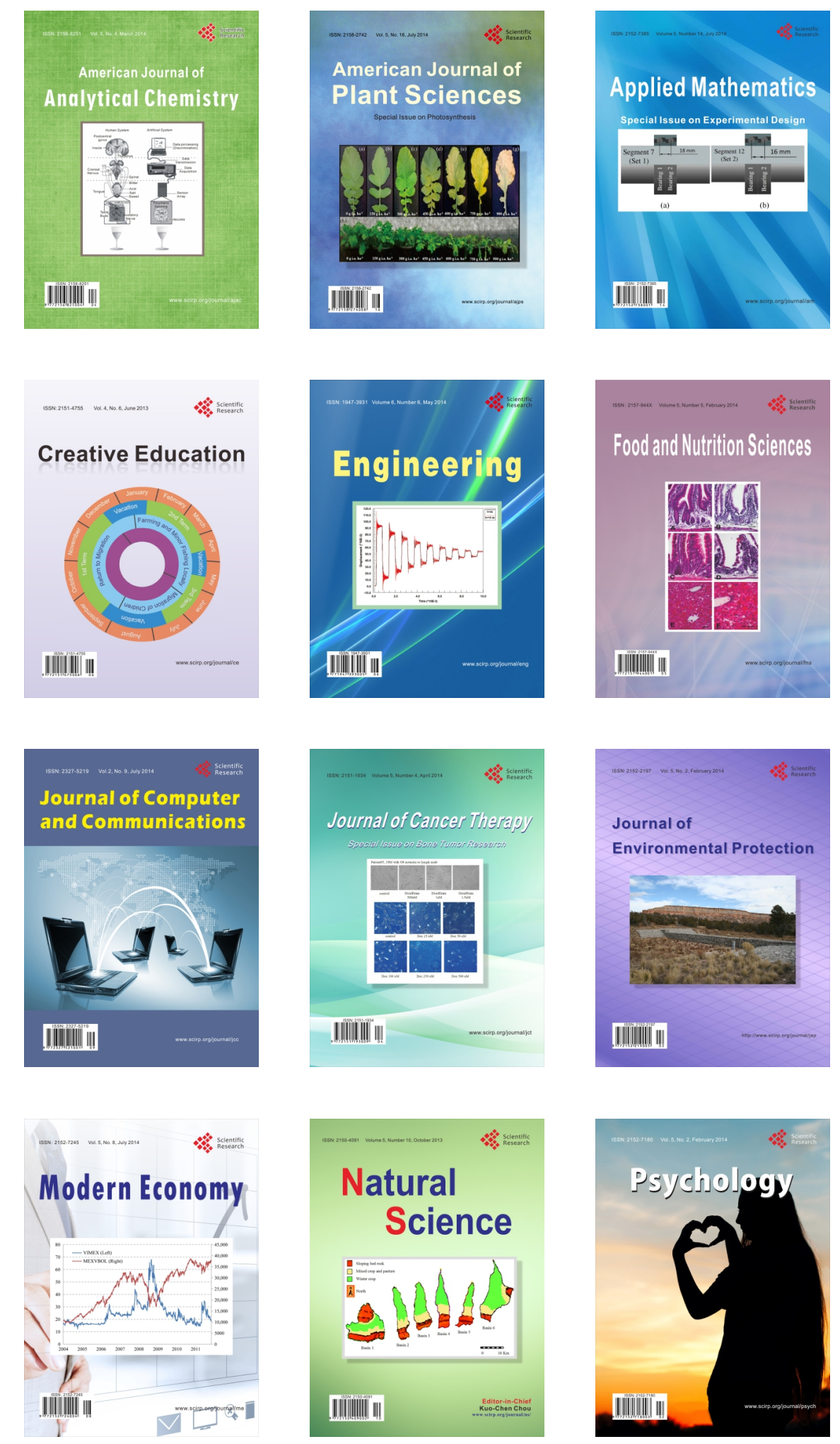